\title{
JOURNAL.RU
}

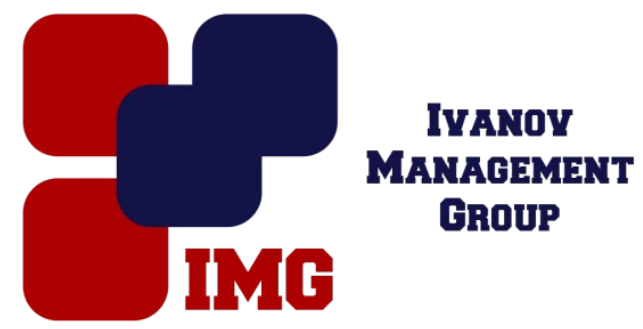

\author{
Горшенев В.Н. ${ }^{1}$, Яковлева М.А. ${ }^{1}$, Телешев А.Т. ${ }^{2}$ \\ ${ }^{1}$ Институт биохимической физики им. Н.М. Эмануэля РАН \\ ${ }^{2}$ Московский Педагогический Государственный Университет \\ Москва, Россия
}

doi: 10.18411/lj-28-02-2017-1-02

idsp 000001:lj-28-02-2017-1-02

\section{Способы очистки синтезированных кальций-фосфатных суспензий от нитрата аммония}

\begin{abstract}
Аннотация
Осуществлен синтез гидроксиапатита в условиях механо-акустической обработки водной реакционной смеси гидрофосфата аммония и нитрата кальция с помощью промышленно значимого роторно-пульсационного аппарата.

Установлено, что, механо-акустическая обработка реакционной смеси позволяет сформировать наноразмерные частицы гидроксиапатита, имеющие преимущественно средний диаметр около 20нм. Предложены способы очистка технического гидроксиапатита от следов нитрата аммония декантацией надосадочной жидкости, ультразвуковой фильтрацией, электрофорезом, термической обработкой синтетического гидроксиапатита. Установлено, что термическая обработка гидроксиапатита не приводит к существенному изменению дисперсности при его диспергировании в воде. Центрифугирование гидроксиапатитовых суспензий приводит к формировании гидроксиапатитового концентрата в пастообразной форме.
\end{abstract}

Ключевые слова: гидроксиапатит, очистка, наночастицы,

\section{Введение}

В настоящее время проблема разработки биоадекватных имплантатов для заполнения и восполнения костных дефектов является актуальной и социально значимой. Важнейшими органическими составляющими костной ткани являются коллаген и протеогликаны, образующие межклеточный матрикс, в котором выстраиваются апатитовые структуры [1-3].

При разработке и создании биоимплантатов в качестве неорганической части костного имплантата широко применяется гидроксиапатит (ГАП). Поэтому одной из основных составляющих частей работы при разработки костезамещающих имплантатов являетсяся синтез ГАП и исследование его свойств. Дисперсионная среда, в которой равномерно распределяется гидроксиапатит, представляет собой гидрогель с коллагеновой дисперсной фазой. Такая композиция является наиболее близкой по своему составу и свойствам к 
костной ткани организма человека и может быть положена в основу создания искусственного заменителя костной ткани.

Синтез кальций-фосфатных соединений, развитие нанотехнологий их получения, по-прежнему, является актуальной задачей. Это связано с тем, что кальций-фосфатные соединения индуцируют биологические реакции, аналогичные протекающим в процессе остеогенеза. Синтез кальций-фосфатных частиц твёрдой фазы для медицинских приложений [4] осуществляют методом осаждения из растворов: 1) нитрата кальция и гидрофосфата аммония, 2) хлорида кальция и гидрофосфата натрия, 3) хлорида кальция и гидрофосфата калия, 4) ацетата кальция и гидрофосфата калия. Для изготовления керамических биокомпозитов в работе [5] из ацетата кальция и гидрофосфата натрия при температуре $600 \mathrm{C}, \mathrm{pH}=14$ реакцию проводили при интенсивном перемешивании. Через 30 минут после взаимодействия реагентов суспензию гидроксиапатита (ГАП) фильтровали на бумажном фильтре водоструйным вакуумным насосом. В результате был синтезирован порошок с максимальным размером частиц порядка 10 мкм и наиболее вероятным размером 3-3,5 мкм. При термической обработке синтезированного порошка в интервале температур 900-11000С наблюдалось уменьшение относительной плотности образцов, как считают авторы работы, за счёт терморазложения карбоната натрия и за счёт образования двойного фосфата кальция натрия. Установлено, что сопутствующие продукты реакции приводят к образованию оксида кальция $(\mathrm{CaO})$, который агрессивен по отношению к живым тканям [5].

Синтез кальцийфосфатных соединений в работе [6] осуществляли гидролизом $\alpha$ - Са3(PO4)2 и отмечали важный параметр для кальцийфосфатных соединений - растворимость. Оказывается, что трикальций фосфат формы $\beta$ Са3(PO4)2 растворяется в биологических жидкостях со скоростью, соответствующей скорости образования новой костной ткани. Состав исходной смеси реагентов существенно влияет на состав конечного продукта: то есть, может быть получен чистый трикальций фосфат или смесь трикальций фосфата с гидроксиапатитом.

В работах [7,8] для получения биокомпозитов применяли кальцийфосфатные порошки, отличающиеся по составу от гидроксиапатита: частицы различных фазовых составов и форм наночастиц: пластинчатые толщиной 0,8-4,5 нм и иглоподобные нанокристаллы диаметром 5-10 нм, длиной 40-50 нм. Установлено, что в зависимости от условий синтеза, фазового состава, структурных, морфологических характеристик, по-разному может проявляться свойство биоактивности частиц ГАП в живых системах. В работе [9] отмечается, что в результате многочисленных экспериментальных исследований определена высокая эффективность для замещения дефектов костной ткани и активизации репаративного остеогенеза биокомпозиционного материала: гидроксиапатита. содержащего коллаген с антибиотиками. Также отмечается необходимость достижения величины макропор в биокомпозите (не менее 300 микрон), что обеспечивает питание клеток, кровоснабжение, клеточное распространение по поверхности макропор и другие процессы. Высокие требования к чистоте имплантатов, отсутствию токсичности распространяются и на компоненты синтезируемых биоматериалов.

Цель работы состояла в синтезе кальций-фосфатной суспензии по реакции ионного обмена в водных растворах диаммонийфосфата, тетрагидрата нитрата 
кальция и гидроксида аммония путем механо-акустической активации реакционных смесей с помощью, роторно-пульсационного аппарата (РПА) и разработке способов очистки кальций-фосфатной суспензии от нитратов аммония.

\section{Экспериментальная часть}

Синтез наночастиц гидроксиапатита осуществляли по реакции обмена (схема 1):

$$
\begin{gathered}
6\left(\mathrm{NH}_{4}\right)_{2} \mathrm{HPO}_{4}+10 \mathrm{Ca}\left(\mathrm{NO}_{3}\right)_{2} \times 4 \mathrm{H}_{2} \mathrm{O}+8 \mathrm{NH}_{4} \mathrm{OH} \rightarrow \\
\mathrm{Ca}_{10}\left(\mathrm{PO}_{4}\right)_{6}(\mathrm{OH})_{2}+20 \mathrm{NH}_{4} \mathrm{NO}_{3}+46 \mathrm{H}_{2} \mathrm{O} \\
(\text { Cхемa } 1)
\end{gathered}
$$

с помощью роторно-пульсационного аппарата (РПА) (Рис.1), позволяющего сформировать в водной среде дисперсию гидроксиапатита [10-13]. Благодаря конструктивным особенностям установки РПА, жидкотекучие среды в зоне обработки подвергаются комплексному механоакустическому воздействию, за счет больших градиентов скоростей, вихреобразования и высокочастотных пульсаций. РПА имеет Санитарно-эпидемиологическое заключение и Сертификат соответствия, разрешающие его использование при производстве продукции широкого профиля.

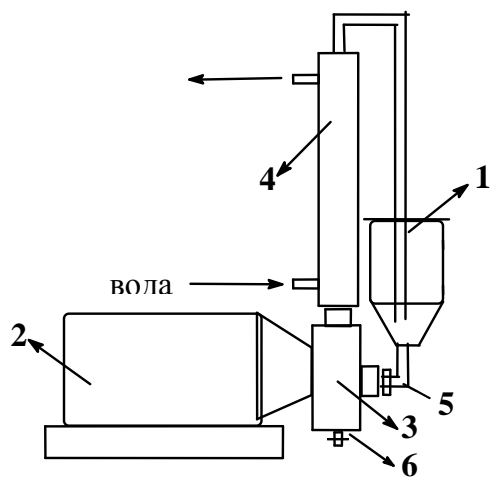

Рисунок 1. Схема подключения РПА: 1) загрузочная емкость, 2) РПА, 3) электродвигатель, 4) холодильник «труба в трубе», 5) термопара, 6) сливной кран.

Тетрагидрат нитрата кальция в количестве 450 г растворяли в 5-ти л дистиллированной воды, добавляли 150 мл концентрированного раствора аммиака доводя $\mathrm{pH}$ смеси до 10,1. (раствор №1). Для приготовления раствора №2 диаммонийфосфат в количестве 151 г растворяли в 2-х л дистиллированной воды и концентрированным раствором аммиака задавали величину рН равную 10,0.

При включенном охлаждении в загрузочную емкость (Рис.1-.1) помещали раствор №1 и запускали двигатель аппарата (Рис.1- 2.3) (2500 мин-1). Со скоростью 1 л/мин в загрузочную емкость вводили раствор №2. Смесь обрабатывали в рабочем режиме аппарата 2 мин. Образец пульпы переносили на вакуум-фильтр. Фильтровали и ретенат многократно промывали горячей водой до рН промывной воды 7,5.

Размеры частиц дисперсной фазы оценивали с помощью метода динамического светорассеяния на приборе Zetasizer Nano ZS Zen3600 «Malvern».

Очистка от нитратов аммония проводили различными способами;

1) декантацией (сменой) надосадочной жидкости;

Для этого добавляли к синтезированной суспензии дистиллированную воду, после чего перемешивали несколько раз и оставляли отстаиваться на сутки, Надосадочную жидкость, в которую переходили нитраты (выход контролировали 
спектрально и по показаниям рН-метра), сливали. К оставшейся массе добавляли новую порцию дисперсионной дистиллированной воды.. Процедуру повторяли 10 раз (т.е. объем промывочной жидкости составил приблизительно 25-30 литров).

Спектр поглощения надосадочной жидкости прописывали на спектрофотометре Shimadzu UV-1700 в кювете на 3мл с длиной оптического пути 1 см. В качестве раствора сравнения выступала вода.

Концентрацию нитратов оценивали по интенсивности поглощения на длинах волн 202 нм и 302 нм. Для этих длин волн были построены калибровочные зависимости оптической плотности от концентрации в растворах нитратов аммония.

\section{2) очистка фильтрацией;}

Суспензию подвергали процессу фильтрации с включением ультразвукового перемешивания по схеме (Рис. 2). После очистки суспензии декантацией суспензия центрифугировалась. Центрифугирование проводилось на центрифуге Allegro 64R, Beckman в режиме 6000 мин-1 по 15-20 мин при 10 оC. В результате такой обработки все образцы суспензий гидроксиапатита приобретали пастообразную консистенцию. Пастообразный продукт реакции после центрифугирования диспергировался в воде с применением ультразвукового диспергатора (УЗДН - А) в течение 3-5 минут. И дальнейшая очистка осуществлялась по методу ультразвуковой фильтрации [14].

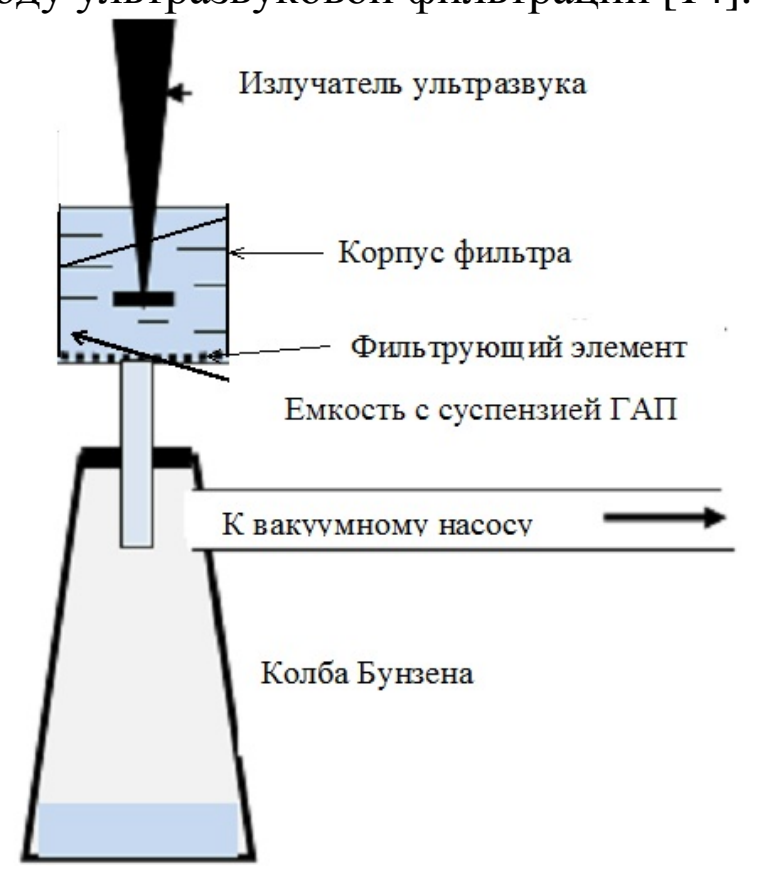

Рисунок 2. Фильтращия суспензии (ГАП) с включением ультразвукового перемешивания.

3) очистка в электрическом поле - удаление нитратов аммония под действием электрического поля (Е).

Для очистки суспензии от нитратов аммония была изготовлены лабораторная установка, схема которой представлена на рисунке 3. 


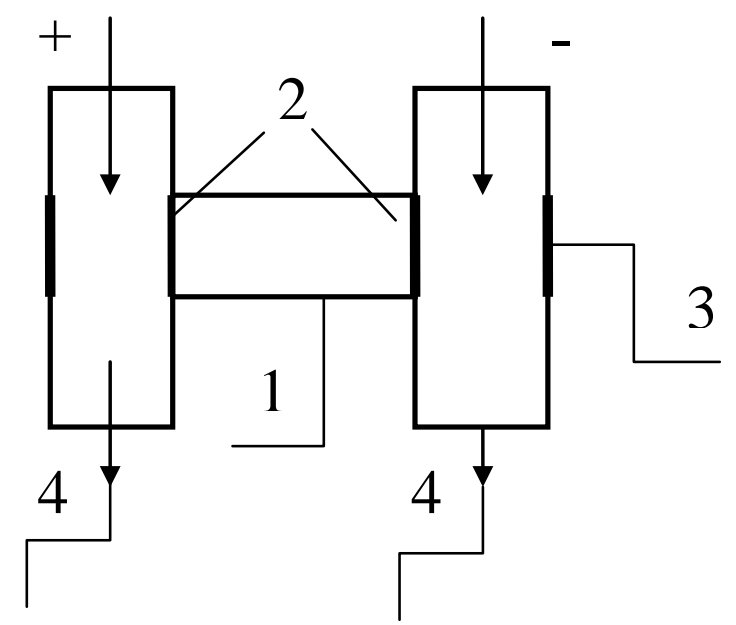

Рисунок 3. Схема очистки кальций-фосфатных суспензий от нитратов аммония под действием электрического поля (Е): 1 - реактор с кальций-фосфатной суспензией; 2 - вставки с диализныли пленками; 3 электроды; 4 - трубки с проточной водой. Очистка под действием электрического поля приводит к движению положительного иона аммония (NH4+) к отрицательному электроду, а движение отрицательного нитрата иона (NO3-) происходит к положительному электроду.

\section{4) термической обработкой в интервале температур 3500С-4000C;}

Методами термогравиметрического анализа (ТГА, на термомикровесах ТG 209 F1 Iris фирмы «Netzsch» (Германия)) и дифференциально-сканирующей калориметрии (ДСК, («Netzsch», Германия, модель DSC-204 F1)) установлены режимы термообработки частиц ГАП, при которых происходит остаточное разложение нитратов аммония. Высушенный после центрифугирования образец пасты гидроксиаппатита помещали в термопечь при температуре $350 \mathrm{oC}-4000 \mathrm{C}$. на 20 минут. По изменениям спектров ИК, УФ-надосадочных жидкостей и методом ДСК контролировали очистку синтезированных частиц ГАП на присутствие нитратов аммония.

Результаты и их обсуждение

В результате проведенных синтезов реакцией ионного обмена между гидрофосфатом аммония и нитратом кальция (1) путем механо-акустической активация водных реакционных смесей с помощью РПА (Рис.1), получаются образцы с дисперсией технического ГАП, характеризующейся частицами, имеющими средний диаметр примерно 20 нм. Массовая доля таких частиц в реакционной среде составляет $\approx 90 \%$ (Рис. 4 ).

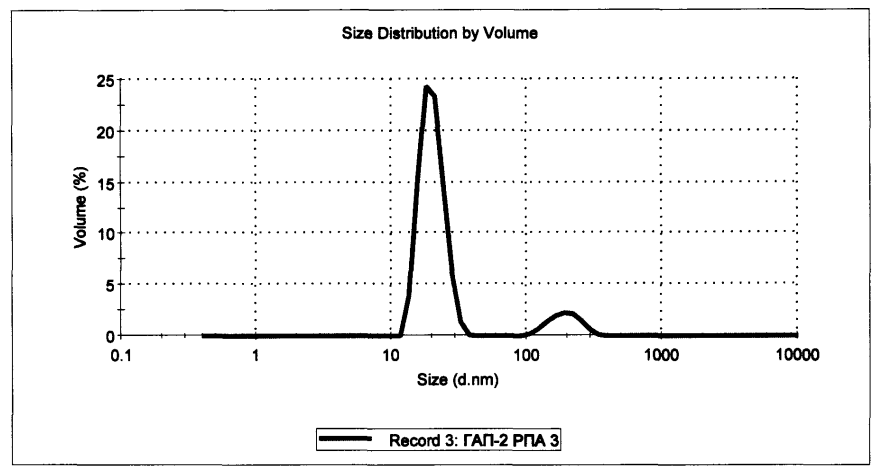

Рисунок 4. Распределение по размерам частии гидроксиапатита, полученного в условиях формируются механо-акустической обработки, скорость вращения ротора РПА 3000 мин-1, скорость введения в реактор раствора диаммонийфосфата $0,5 \mathrm{\pi} /$ мин. 
В синтезированных суспензиях содержится большое количество нитрата аммония. Поэтому очистка от нитратов аммония осуществлялась различными способами, изготавливались лабораторные установки и, для оптимизации процесса очистки, определялась эффективность применяемых способов.

Так как нитрат аммония является важным химическим продуктом, то его сохранение в процессе очистки решается с применением разрабатываемых способов. Оценка содержания нитратов аммония по спектрам УФ проводилась в основном на начальных стадиях очистки суспензий декантацией при высоких концентрациях нитрата аммония. Результаты спектральных исследований исходных реагентов (Рис. 5) демонстрируют, что в спектральной области УФ на интенсивность спектров суспензий ГАП могут влиять присутствующие в растворах реагенты.
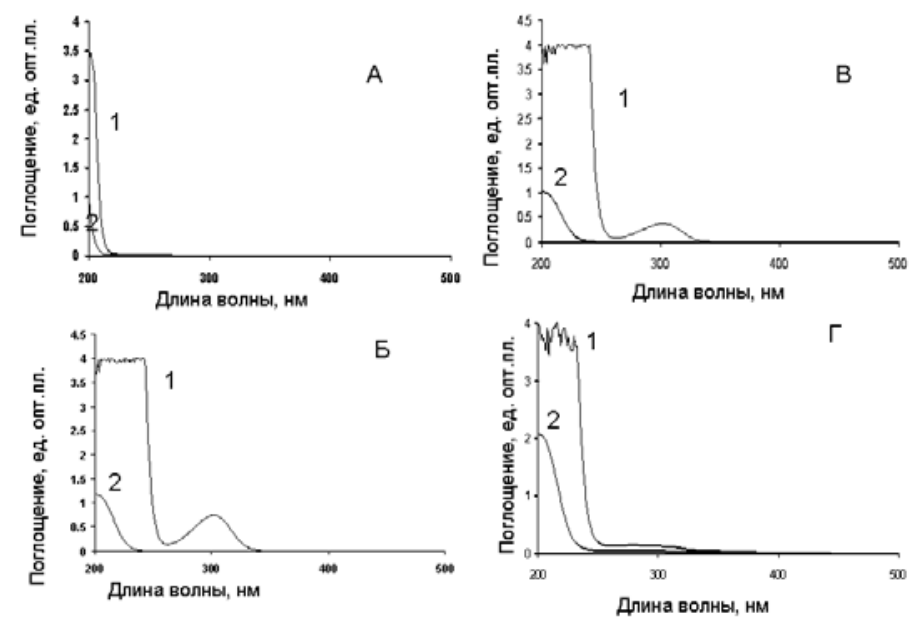

Рисунок 5. Спектры поглощения стандартных растворов соединений, участвующих в реакции синтеза ГАП, а также суспензии синтезированного ГАП. А- (NH4)2HPO4, Б- (NH4)NO3, B - Ca(NO3)2, Г- суспензия ГАП 1 - концентрированный раствор, 2 -разбавленный раствор.

Как видно из спектров поглощения (Рис. 5) растворов веществ, участвующих в реакции по синтезу ГАП, все компоненты поглощаю в области 200нм, однако только нитраты обладают поглощением и в области 302нм. Видно, что оба этих максимума присутствуют в спектре суспензии синтезированного технического ГАП. Таким образом, после синтеза частицы ГАП по ионнообменной реакции необходимо проводить очистку от нитратов. Очистка декантацией приводит к длительному процессу очистки с большим расходом воды. Сменой надосадочной жидкости удается отмывать гидроксиапатит от нитрата аммония (Рис. 6).

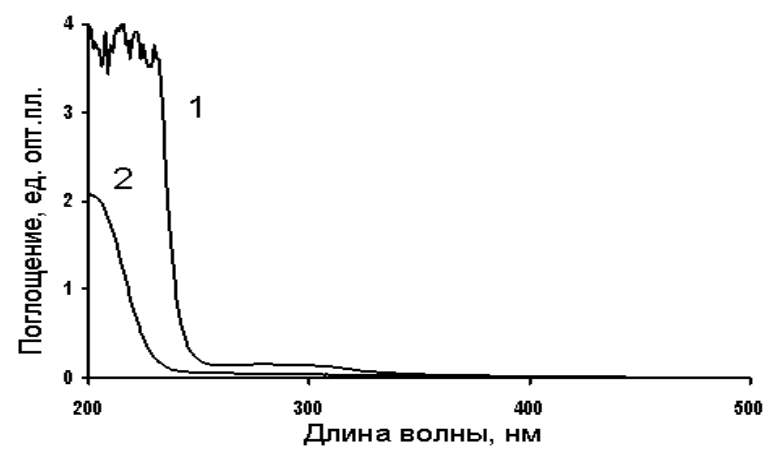

Рисунок 6. Спектр поглощения до и после очистки декантаиией суспензий ГАП. 1- исходный образеи ГАП, 2 - образеи 1 после шести отмывок водой. 
Спектр надосадочной жидкости на рисунке 6 свидетельствует о присутствии нитрата аммония. Кривая 1 - исходный образец после синтеза (концентрация нитратов 23,83 мМ на длине волны 302нм), кривая 2 - образец 1 после того, как его подвергли 6 раз очистке отмывкой в дисперсионной среде (концентрация нитратов 0,36 мМ на длине волны 202нм). Видно, что после 6 отмывок концентрация нитратов в образце 2 упала за 6 отмывок в 65,5 раз.

После очистки декантацией суспензии центрифугироваласьи проводилась ультразвуковая фильтрация на установке (Рис. 2) в течение 5-8 часов. При реализации метода ультразвуковой фильтрации [14], когда фильтруемый материал постоянно диспергировался в реакторе (Рис. 2), через который поступала вода, процесс очистки ускоряется.

Результаты очистки гидроксиапатитовых суспензий декантацией, фильтрацией в проводимом объёме не приводят к полному удалению нитратов. Фильтрование пульпы, трёхкратная промывка ретената водой, его сушка при температуре $120 \mathrm{oC}$ в течение 3-х ч приводит к образцу гидроксиапатита, загрязненного нитратом аммония (полосы поглощения 1330, 820 см-1) (Рис. 7).

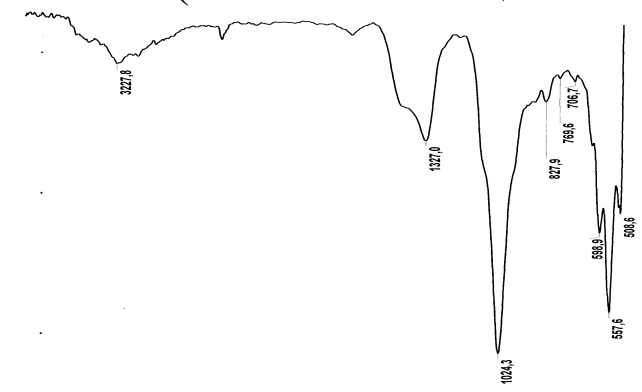

Рисунок 7. ИК-спектр образиа гидроксиапатита, загрязненного нитратом аммония. Спектрометр Nicolet 380, стекло ZnSe.

Дальнейшая очистка суспензий проводилась с применением электрического поля (Рис.3). Очистка под действием электрического поля приводит к движению положительного иона аммония (NH4+) к отрицательному электроду, а движение отрицательного нитрата иона (NO3-) происходит к положительному электроду.

В реактор (1) (Рис.3) помещалась кальций-фосфатная суспензия. Торцы реактора закрывались диализной плёнкой. Через трубки с проточной водой продукты электрофореза удалялись. Электроды (3) изготавливались из платины (так как с латунными электродами частицы гидроксиапатита окрашивались в синий цвет за счёт ионов меди).

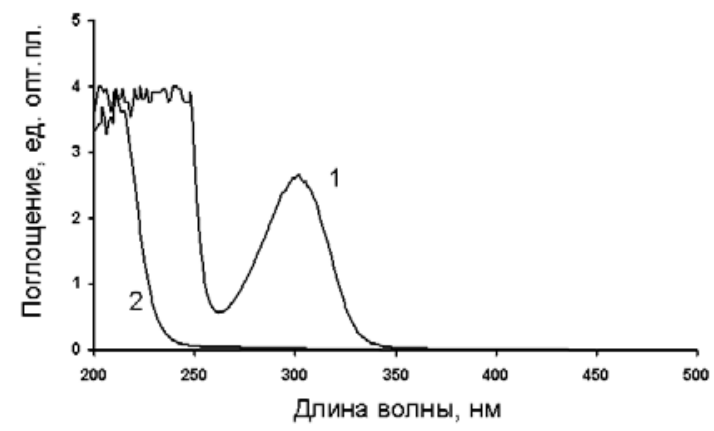

Рисунок 8. Спектры поглощения до и после очистки суспензий ГАП в электрическом полем. 1 - раствор до электрофореза. 2 - раствор после воздействия электрического поля на суспензию ГАП-2. 
Способ очистки кальций-фосфатных суспензий под действием электрического поля можно применять для доочистки суспензий после многократной промывки водой. На рисунке 8 приведены результаты очистки под действием электрического поля (начальный ток в цепи - 10ma, напряжение -30в).

Спектр надосадочной жидкости на рисунке 8 свидетельствует о присутствии нитрата аммония. Кривая 1- высушенный путем центрифугирования образец пасты гидроксиаппатита- исходный образец (439,7 мМ нитратов на длине волны 302нм), кривая 2 - образец 1 после того, как его подвергли действия электрического поля в течение суток (4,7 мМ нитратов на длине волны $302 \mathrm{Hм})$. Видно, что концентрация нитратов в образце упала в 93,6 раза.

Спектры растворов надосадочной жидкости после центрифугирования суспензий (Рис. 8) показали, что можно доочищать от нитратов аммония суспензию под действием электрического поля по схеме, представленной на рисунке 3.

При выборе условий проведения очистки гидроксиапатитовых концентратов под действием электрического поля и изготовлении соответствующего оборудования эффективность и скорость очистки может значительно возрасти. Результаты очистки (Рис. 8) показали снижение концентрации нитратов 93,6 раза при токе 10ma в течение суток.

Очистка частиц, суспензий ГАП от нитратов аммония перспективна и эффективна, но требуется создание необходимого оборудования. Высушенный после центрифугирования образец пасты гидроксиаппатита после предварительной очистки методом 1 (декантацией) прогревали в термопечи при температуре $350 \mathrm{oC}$ в течение 20 минут. В результате термической обработкой в интервале температур 3000С-4000С гидроксиапатитового концентрата в термошкафу в течение 20 -30 минут происходит разложение нитрата аммония по реакции [4]:

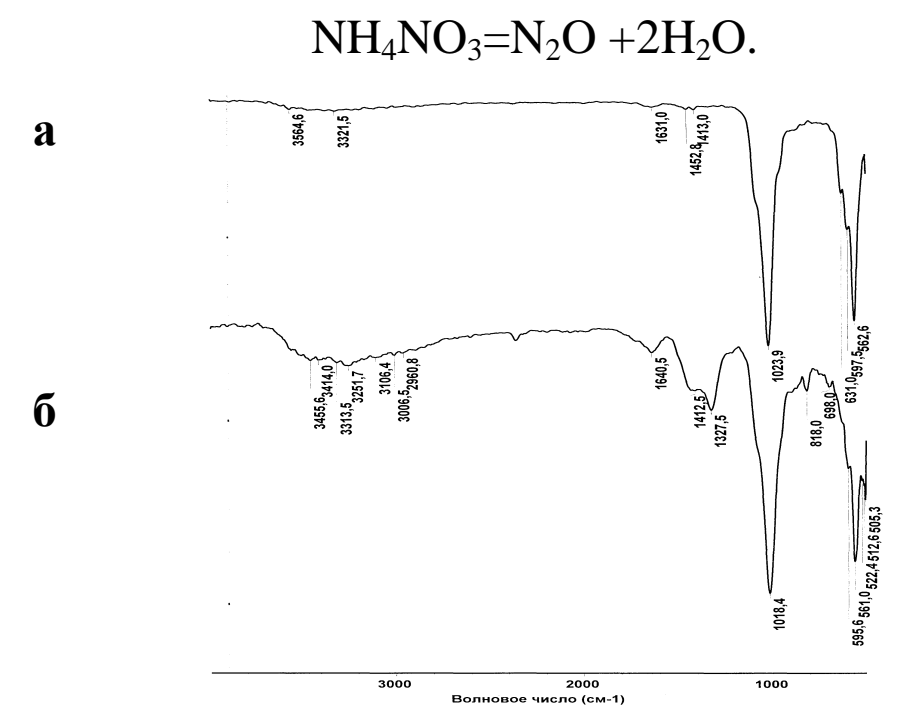

Рисунок 9. ИК-спектры: а) ГАП прогретого при 350 С в течение 20 мин, б) исходного неочищенного ГАП. Спектрометр Nicolet 380 (кристалл ZnSe).

В ИК-спектре отражения прокалённого образца характерная для нитрата аммония полоса поглощения в области 1330 см-1 не обнаруживается (Рис. 9а). В отражательном ИК-спектре твердого ГАП, подвергшегося термообработке при 350 oC, не зарегистрировано присутствие характерных для NH4NO3 полос 
поглощения в области 1330, 820 см-1. Это отличает термообработанный ГАП от исходного технического образца ГАП (Рис. 9б).

ИК-спектр термообработанного очищенного ГАП близок по своим параметрам к спектру чистого Са3(PO4)2, что подчеркивает отсутствие в образце нитрата аммония (Рис. 10).

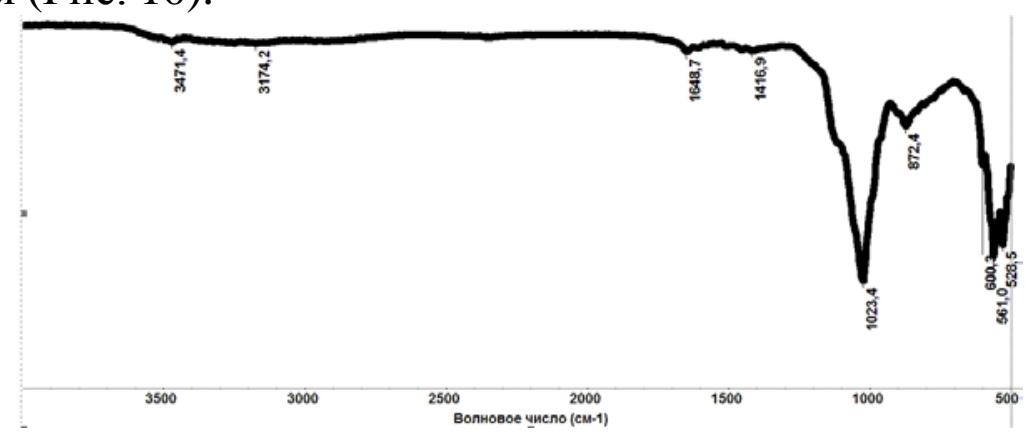

Рисунок 10. ИК-спектр чистого Са3(РО4)2.

Данные элементного анализа очищенного ГАП, проведенные на CHNанализаторе Eager 300, подтверждают полное отсутствие азотсодержащих примесей в термобработанном ГАП (эталон - нитрат аммония).

Дополнительным подтверждением отсутствия нитрата аммония в образце ГАП прогретого при 350оС служат результаты калориметрического эксперимента (Рис. 11).

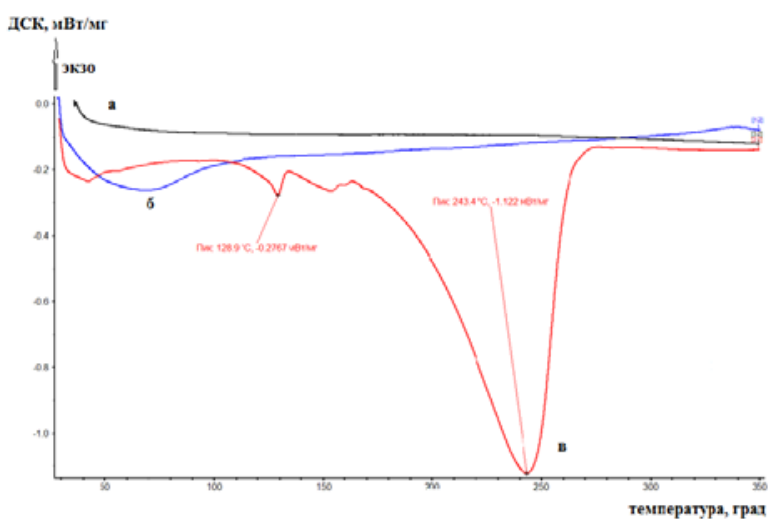

Рисунок 11. Калориметрические кривые: а - ГАП, прогретого при 350 оС, б- технического ГАП, внитрата аммония.

После тепловой обработки образец ГАП подвергли дополнительной очистке декантацией, после чего был получен совершенно чистый образец ГАП (Рис. 12).

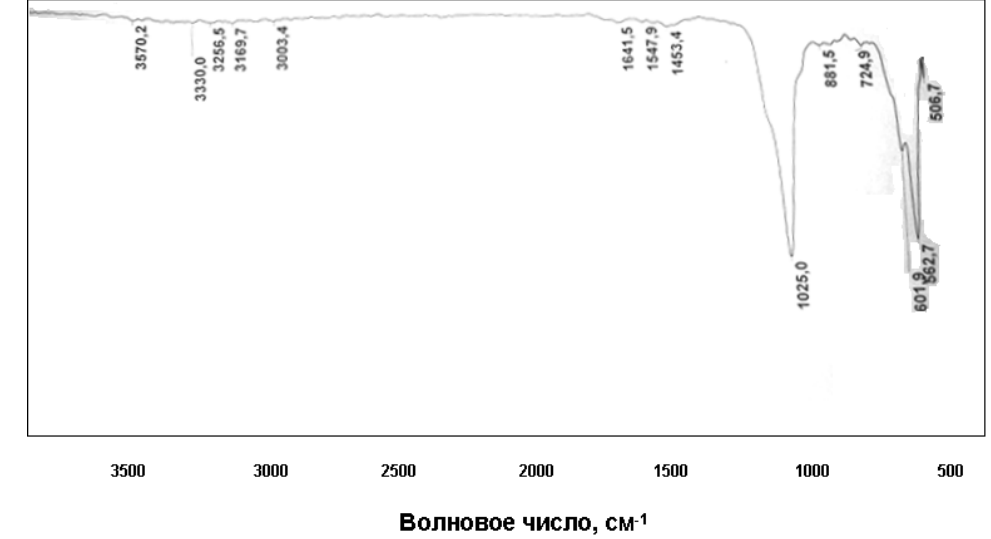

Рисунок 12. ИК-спектры ГАП, прогретого при 350 оС в течение 20 мин, и затем очищенного декантацией. Спектрометр Nicolet 380 (кристалл ZnSe). 
Дополнительная проверка очищенного образца ГАП на токсичность надосадочной жидкости показала, что для клеток указанный образец не оказывает повреждающего влияния. Необходима стадия контроля токсичности как синтезированных порошков ГАП, так и надосадочной жидкости при образовании из порошка ГАП пасты. Проверка поведения клеток в растворах нитратов показала 100\%-ю выживаемость клеток.

Однако, для очистки суспензий ГАП, содержащих органические компоненты способ очистки от нитратов должен исключать термическую обработку суспензий, поэтому в этом случае необходимо развивать способ очистки с использование, например, электрического поля.

Для сохранения ценного продукта нитрата аммония и получения гидроксиапатита высокой чистоты разрабатывается пилотная технология синтеза, выделения продуктов синтеза их очистка с учётом полученных результатов.

\section{Выводы}

1. Осуществлен синтез гидроксиапатита в условиях механоакустической обработки водной реакционной смеси гидрофосфата аммония и нитрата кальция с помощью промышленно значимого роторно-пульсационного аппарата. Установлено, что, механоакустическая обработка реакционной смеси позволяет сформировать наноразмерные частицы гидроксиапатита, имеющие преимущественно средний диаметр около 20 нм.

2. Предложена очистка технического гидроксиапатита от следов нитрата аммония различными способами, а именно декантацией, фильтрацией, под действием электрического поля и термическим способом. 


\section{Литература}

1. Boskey A.L., «Bone mineralization» in Bone Biomechanics, S. C. Cowin, Ed., pp. 5.15.34, CRC Press, Boca Raton, Fla, USA, 3rd edition, 2001.

2. Harada S.I., Rodan G.A. Control of osteoblast function and regulation of bone mass. Nature.Vol. 423, no. 6937, pp. 349-355, 2003.

3. S.Weiner and H. D.Wagner, "The material bone: structure-mechanical function relations," Annual Review of Materials Science, vol. 28, no. 1, pp. 271-298, 1998.

4. Сафронова Т.В, Шехирев М.А., Путляев В.И.,Третьяков Ю.Д. Неорганические материалы,2007, том43,№8, С.1005-1014.

5. 5.Т.В.Сафронова, А.В.Кузнецов, В.И.Путляев, А.Г.Вересов,В.К.Иванов. Керамика на основе гидроксиапатита, синтезированного из ацетата кальция и гидрофосфата натрия. Перспективные материалы. 2008. С.96-99.

6. О.В. Синицына,А.Г. Вересов, Е.С. Ковалёва, Ю.В. Коленко, В.И Путляев , Ю.Д Третьяков. Известия Академии наук. Серия химическая, 2005, №1, С. 78-85.

7. Stevens M.M. Biomaterials for bone tissue engineering. Materials Today.2008, v,11, no,5, p,18-25,

8. $\quad$ Sun J,S., Tsuang Y.H.,Liao C.J., Hang Y.S., Lin F.H. The effect of sintered - dicalcium phosphate particale size on newbom wistar ratosteoblasts. Atifinal Organs, 1999, v.23, no.4, p.331-338.

9. Г.Н. Берченко. Синтетические кальций-фосфатные материалы в травматологии и ортопедии. Всесоюзная научно-практическая конференция. «Применение искуственныхкальциево-фосфатных биоматериалов в травматологии и ортопедии. M.2010, C. 3-5.

10. Горшенев В.Н., Телешев А.Т., Ершов Ю. А., Казиев Г. З., Колесов В. В.. Склянчук Е. Д. Способ получения пористого костного биокомпозита // Пат. РФ № 2482880. 2013. БИ №15. 2013.

11. Просвирин А.А., Склянчук Е.Д., Гурьев В.В., Горшенев В.Н., Телешев А.Т., Акатов В.С., Фадеева И.С., Фадеев Р.С. , Шушкевич А.М. Физико-химические свойства и биосовместимость наноструктурированного пористого костного имплантата. Технологии живых систем, Т.10, №8. 2013. С.68-73.

12. КесельБ.А., ФедоровА.Д., ГимушинИ.Ф. КесельБ.А.; ФедоровА.Д.; ГимушинИ.Ф.; ВолковГ.А.; ГатауллинР.Ш.; ВоскобойниковД.В.; ВесельевД.А. Роторнопульсационныйаппарат (рпа) // Патент №2166986 (РФ). БИ. 2006, 11.

13. Горшенев В. Н., Ершов Ю.А., Телешев А.Т., Склянчук Е.Д., Просвирин А.А.5, Григорьев С.А. Гидроксиапатитовые биокомпозиты медицинского назначения. Медицинская Техника, 2014, №1(283), С. 30-33.

14. Акопян В.Б. Ершов Ю.А. Основы взаимодействия ультразвука с биологическими объектами М. Юрайт, 2016, С. 223. 